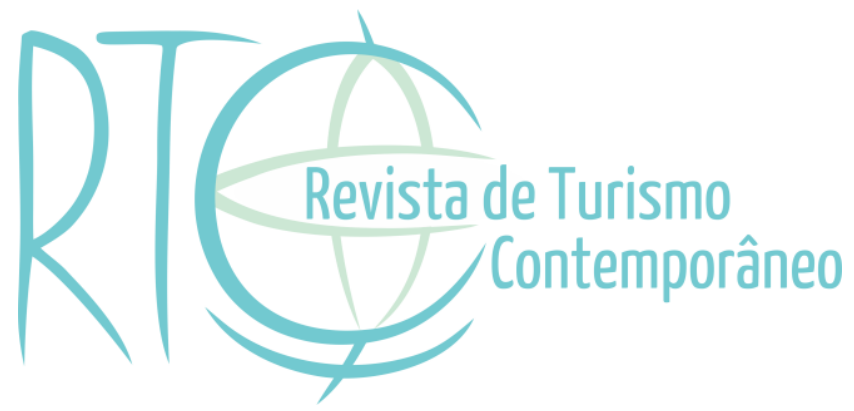

\title{
Fazenda Santo Antônio do Paiol, Valença/RJ: pioneirismo em serviços de hospitalidade
}

Fazenda Santo Antônio do Paiol, Valença/RJ: pioneering hospitality services

Dan Gabriel D'Onofre Andrade Silva Cordeiro

Professor Adjunto C1 do Departamento de Economia Doméstica e Hotelaria da Universidade Federal Rural do Rio de Janeiro - UFRRJ, Rio de Janeiro/RJ, Brasil

E-mail: donofretur@gmail.com

Artigo recebido em: 17-08-2019

Artigo aprovado em: 12-12-2019 


\section{RESUMO}

Localizada em Valença/RJ, a Fazenda Santo Antônio do Paiol teve sua fundação ligada ao cafeicultura imperial. No século XIX, a economia baseada no plantation, tendo o café como principal gênero de produção, conduziu da ocupação do território resultando impactos de diversas ordens. Durante o período de maior acumulação monetária da cafeicultura imperial, suntuosas sedes de fazendas foram erguidos por todo Vale do Paraíba fluminense. Nesse sentido, o presente trabalho se dedica a discorrer sobre o processo de abertura de visitação da Fazenda Santo Antônio do Paiol, liderada por Dona Francisca Olympia Alves de Queiroz Esteves, ainda na década de 1960. Para tanto, através de uma abordagem qualitativa, a pesquisa foi conduzida tendo como instrumentos a coleta de imagens por fotografias, bem como a aplicação de formulários junto aos anfitriões atuais. Para além da observação participante, posto que o pesquisador esteve a conviver com os entrevistados, bem como a consumir os serviços de hospitalidade ofertados junto à Fazenda Santo Antônio do Paiol, os dados coletados em diário de campo, somado aos demais obtidos pelos instrumentos supracitados, foram analisados por triangulação. Vale destacar que, o artigo também se consolidou através de uma pesquisa histórica, com base nos dados secundários advindos da produção da área da história, da arquitetura e da economia. Por fim, destaca-se que, de modo inusitado, a Fazenda Santo Antônio do Paiol é uma das pioneiras na oferta de hospitalidade comercial em pleno início da segunda metade do século XX, no sul do Estado do Rio de Janeiro.

Palavras-chave: Vale do Café. Hospitalidade. História.

\section{ABSTRACT}

Located in Valença /RJ, Fazenda Santo Antônio do Paiol had its foundation linked to imperial coffee growing. In the 19th century, the plantation-based economy, with coffee as the main production genre, led to the occupation of the territory resulting in impacts of different orders. During the period of greatest monetary accumulation in imperial coffee farming, sumptuous farm headquarters were built throughout the Paraíba Valley in Rio de Janeiro. Hereupon, the present work is dedicated to discussing the process of opening visits to Fazenda Santo Antônio do Paiol, led by Dona Francisca Olympia Alves de Queiroz Esteves, still in the 1960s. For this purpose, through a qualitative approach, the research was conducted using the collection of images by photographs as instruments, as well as the application of forms with the current hosts. In addition to participant observation, since the researcher was living with the interviewees, as consuming the hospitality services offered at Fazenda Santo Antônio do Paiol, the data collected in the field diary, added to the others obtained by the aforementioned instruments, were analyzed by triangulation. It is worth mentioning that the article was also consolidated through historical research, based on secondary data from the production of the area of history, architecture and economics. Finally, it is noteworthy that, in an unusual way, Fazenda Santo Antônio do Paiol is one of the pioneers in offering commercial hospitality in the beginning of the second half of the 20th century, in the south of the State of Rio de Janeiro.

Keywords: Vale do Café. Hospitality. History. 


\section{INTRODUÇÃO}

Uma fazenda apenas não consolidou a cafeicultura fluminense no período imperial. Todo processo teve como liderança ímpetos que visavam a exploração da gente e da terra do Vale do Paraíba para produção de café. O que a historiografia tem dado conta é de ressaltar os aspectos centrais do avanço da produção do café, bem como os impactos sociais e ambientais desse período da história do Rio de Janeiro e, por que não, do Brasil.

Com o intuito de trazer à tona alguns elementos até então não divulgados, a presente pesquisa se dedica em permitir conhecer algumas das bases da comercialização de serviços de hospitalidade (Camargo, 2003; Lashley, 2004) em pleno Vale do Café fluminense. A região que tem reconhecido legado do período em que a cafeicultura estabeleceu as bases para a sociedade que se erigiu ali, guarda ainda muitos segredos e contradições ligados aos movimentos econômicos, políticos e sociais locais. A fim de permitir um aprofundamento das relações ligadas ao universo da hospitalidade, este artigo se centra na Fazenda Santo Antônio do Paiol, uma das unidades históricas e inventariadas que desenvolve a produção de diversos serviços de hospitalidade comercial.

Assim, para consubstanciar a discussão, apresentam-se nos demais capítulos o desenvolvimento de narrativas históricas baseadas em dados secundários, os quais são trabalhados a partir de uma perspectiva econômica que se debruça no que hoje é a região turística do Vale do Café. Em seguida, busca-se focalizar a história da Fazenda Santo Antônio do Paiol, por intermédio de abordagem qualitativa com método indutivo que se utiliza de pesquisas históricas, análises in loco, bem como dados obtidos por entrevistas, observação participante e captação de som e imagens durante 2016 a 2017. As imagens, por exemplo, constituem neste trabalho um instrumento importante para não apenas ilustrar o local pesquisado, mas trazer recursos importantes para confirmar os movimentos efetuados por anfitriões. Por fim, apresentam-se algumas reflexões que mais se dedicam a indicar caminhos de pesquisas futuras, sem deixar de lado a oportunidade de indicar os avanços que esta pesquisa possui. 


\section{A HISTÓRIA ECONÔMICA NO CONJUNTO DO VALE DO CAFÉ}

A história da Fazenda Santo Antônio do Paiol tem íntima relação com a expansão da cafeicultura no Vale do Paraíba fluminense ${ }^{1}$. A condução do processo de inserção da tecnologia de produção do café no século XIX, somada à estrutura social que se sedimenta ao sabor do crescimento dos rendimentos e dos cafezais, forma o conjunto basilar para a produção e o consumo dos serviços de hospitalidade comercial na região em questão (D’Onofre, 2017). Por conta desses elementos, os quais são fundamentais para compreensão do fenômeno ligado ao surgimento, já na segunda metade do século XX, faz-se necessário recordar como o processo de consolidação da cafeicultura se deu no território em questão.

O que hoje é a região turística do Vale do Café2 fluminense se situa nas divisas com os estados de São Paulo e Minas Gerais pelo lado sul. No Mapa 1 (ver a seguir), é possível verificar a representação geográfica que mostra o recorte territorial em questão circulado de vermelho.

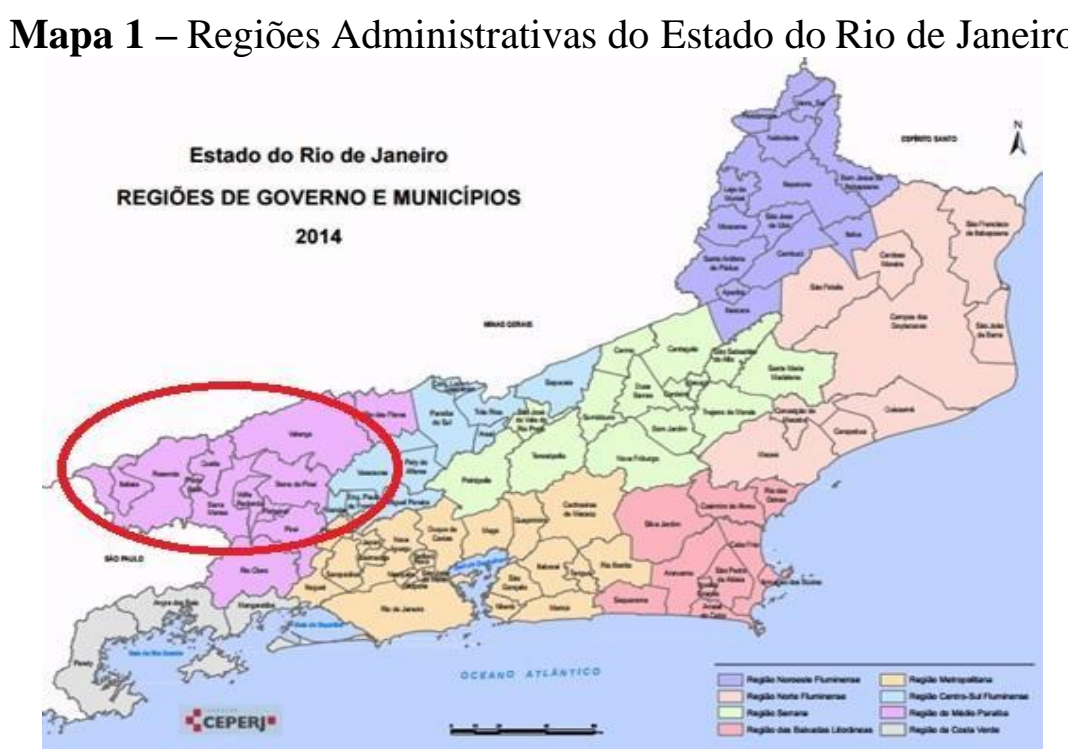

Fonte: Rio de Janeiro, 2014.

\footnotetext{
${ }^{1}$ Com fins de orientação, ressalta-se que o Vale do Paraíba se desdobra logicamente pelo curso do Rio Paraíba do Sul, cuja nascente está no estado de São Paulo. Este rio nomeia também a Bacia Hidrográfica homonimamente, tendo a mesma cerca de $56.500 \mathrm{~km}^{2}$ de extensão, contendo recortes dos estados do Rio de Janeiro e Minas Gerais, também. Ainda assim, o Rio Paraíba do Sul corre a porção final da Serra do Mar, pelo que se convencionou chamar de Vale do Paraíba. Ainda que haja a porção paulista, neste trabalho, estamos em si nomeando Vale do Paraíba o que Vieira (2000) classifica como Zona Serrana do Centro, a qual engloba os municípios de Barra Mansa, Barra do Piraí, Piraí, Paraíba do Sul, Petrópolis, Resende, Sapucaia, Valença e Vassouras.

${ }^{2}$ A região turística do Vale do Café é uma das disputas políticas entre os diversos qualitativos para compreender o território em questão. Rompendo com a determinação político-administrativa, bem como a geológica, o Vale do Café traz em si disputas que estão ligadas ao domínio do turismo sob a dinâmica social do Sul Fluminense (ver mais em D’Onofre, 2017).
} 
Vale dizer que o que hoje é o estado do Rio de Janeiro, teve por parte do estado colonial a iniciativa tardia de ocupação de suas áreas montanhosas. Muito disso se deve pela predileção das elites que ocupavam o poder do Rio de Janeiro, tanto privilegiar a produção da cana de açúcar, como o fato de este território possuir três grandes planícies próximas ao mar. Ou seja, do século XVII ao XIX, a cultura da cana de açúcar foi o principal veio condutor econômico fluminense, sobretudo porque os derivados canavieiros serviam de mediação econômica entre os portos do Rio de Janeiro no comércio triangular onde açúcar e cachaça saíam daqui rumo aos portos lusitanos e da África para mediar a vinda de africanos escravizados e bens manufaturados que vinham da Europa.

A riqueza do período canavieiro se dera por inúmeros eventos. Vale dizer que, o que hoje é o Nordeste brasileiro fora a maior região produtora de açúcar durante a maior parte da história econômica do Brasil Colônia. Ocorre que durante as Invasões Holandesas, a produção brasileira de açúcar que passou a abastecer a Europa advinha sobretudo das capitanias litorâneas do que hoje é o Rio de Janeiro (Lamego, 1963). Mais tarde, o que hoje é o Sudeste brasileiro também experimentou um novo processo econômico: a mineração.

De modo sucinto, aventureiros e escravizadores de indígenas que rumaram a partir do planalto paulista, encontraram jazidas de pedras preciosas no atual estado de Minas Gerais. Isso, por si só, fez com que os ímpetos da metrópole portuguesa passassem a privilegiar os processos de condução da economia advinda da exploração de pedras preciosas, fato que mudou até mesmo a capital da colônia, de Salvador para o Rio de Janeiro, em 1763. Isto é, a partir do fim do século XVII, será o Sudeste a região mais rica da colônia, sendo o Ciclo do Ouro e Pedras Preciosas a sucessão do Ciclo da Cana de Açúcar.

Após o auge da mineração, a coroa portuguesa encontrava-se em desvantagens imensas no conjunto da economia e política europeias. O século XIX iniciava com a exaustão das reservadas de ouro e metais preciosos na região de Minas Gerais, com o avanço da política econômica de Napoleão e o Bloqueio continental à Inglaterra, principal parceira econômica de Portugal. A novidade que iria aguçar o cenário político daquele momento fora não apenas a vinda da família real para o Rio de Janeiro, como também o crescimento da produção e do consumo de café.

Em 1808, a família real da Casa de Bragança teve como ímpeto deixar Portugal durante o período de expansão napoleônica tanto para não perder sua posição de monarquia regente de todo império lusitano e suas colônias ultramarinas, como também para continuar o processo de reprodução de seu poder. O que torna inusitado o processo é que ao virem para o Rio de Janeiro, monarcas e a Corte trasladam a capital para as Américas. Nesse contexto, 
iniciativas ligadas à necessidade de haver novos regimes econômicos alçam o café como um dos novos elementos de enriquecimento da aristocracia sudestina, bem como os cofres da coroa.

Enquanto gênero vegetal, o café se adaptava de forma muito mais vigorosa em terrenos montanhosos, fato que ficou inclusive muito difuso quando o plantio deste gênero vegetal alastrou-se pelo maciço da Tijuca. A voracidade das lideranças que cultivavam café em expandir as plantações levou a cidade do Rio de Janeiro, já na segunda metade do século XIX, a enfrentar escassez de água. Se o fato de lembrar que os produtores de cana de açúcar estavam instalados já nas planícies fluminenses e que as áreas montanhosas ainda eram tidas como "vazios demográficos"

Todavia, as áreas do planalto fluminense ${ }^{3}$ não estavam vazias. Ali, ainda resistiam os puris e os coroados, dois povos originários do tronco macro-jê que se diferenciavam dos tupis que viviam no litoral (Oliveira, 2012). Os puris e os coroados conseguiram permanecer dominando o território escarpado do planalto fluminense enquanto os donos de terras das baixadas não se interessavam em ocupá-lo. Como o café é um elemento vegetal que possui características muito particulares quanto à aclimatação, perfil de desenvolvimento e adaptação ao solo, a cafeicultura não competia com a cana de açúcar (Lamego, 1963).

Ainda que possa parecer lugar comum acionar sucintamente os elementos históricos que formam a economia do estado do Rio de Janeiro, em especial aqueles ligados ao recorte territorial da pesquisa, vale salientar que todo elemento de consolidação dos ciclos econômicos estiveram lastreados pela produção de itens primários. Ou seja, ainda que houvesse algum encadeamento com iniciativas de beneficiamento, sobretudo através dos engenhos fluminenses, o processo de produção do café, por exemplo, agregava baixo potencial industrial ainda no século XIX.

Além disso, o modelo de expansão da fronteira agrícola fluminense teve mais elementos que tiveram íntima relação com a construção das sedes das fazendas. Ao passo que subir ao planalto fluminense permitiu algum relaxamento na forma de reprodução social das elites agrárias locais, pois além de ampliar o acesso à terra, garantiu também que as formas de manutenção desse poder permanecesse sendo perpetuado sob bases de trabalho escravo e intensa devastação da massa vegetal que antecedeu os cafezais. Há de se dizer que as fazendas, como a Santo Antônio do Paiol, foram fomentadas pelas mudanças nos hábitos de

\footnotetext{
${ }^{3}$ Lamego (1963) credencia como planalto fluminense as regiões altas que se sobressaem das planícies costeiras do estado do Rio de Janeiro. O planalto fluminense inclui, ainda, a Serra do Mar, que finda no Estado do Rio de Janeiro.
} 
consumo no século XIX. O café que até então possuía uma certa aura de luxo, passa a ser “combustível" para as massas trabalhadoras das nascentes indústrias na Europa e nos Estados Unidos.

Ao passo que estas indústrias se expandiam, mais trabalhadores industriais passam a ser incorporados nas fábricas e mais café era demandado. Ou seja, conforme aumentavam as taxas de lucro das elites industriais europeias, a cada xícara de café sorvida pelos trabalhadores das fábricas do Norte global, mais linhas de cafezais se abriam, mais trabalhadores escravizados eram explorados, mais pressão ao meio ambiente do Vale do Paraíba era promovida. Segundo o autor, diversos fatores se relacionaram, a provocar uma intensa migração para o planalto com destaque para:

(i) a elevação do preço do café nos mercados europeus;

(ii) o surgimento do emergente mercado consumidor estadunidense, que não desejava comercializar com as colônias e mercados de sua antiga metrópole, a Inglaterra;

(iii) a ambição dos senhores de engenhos das baixadas do Rio de Janeiro, pois, de acordo com Lamego (1963), alguns desse produtores de cana-de-açúcar se tornaram cafeicultores; e

(iv) a busca pela manutenção do poder de elites mineiras que passaram a ter seus rendimentos diminuídos, as quais deixam as áreas de extração de ouro e metais preciosos, indo em busca de terras no planalto fluminense.

Por conta das características relacionadas à topografia de regiões montanhosas, Lamego (1963) afirma que o principal empecilho à ocupação do Vale do Paraíba era a densa massa vegetal que o encobria. Nunca antes se havia visto tamanha devastação do patrimônio natural. Pelas palavras de Lamego:

Na Serra, entretanto, a ofensiva do café contra a floresta foi repentina e acelerada. O
machado precedera ali, ademais, o gado, impossibilitando o transporte da madeira, e,
a rapidez do plantio dos grandes cafezais cada vez maior com a crescente invasão
serrana a partir dos começos do século passado, resultou na derrubada em massa do
matagal sem uma seleção e um corte inicial das espécies vegetais de valor pela
durabilidade. As mais preciosas madeiras de lei incineravam-se em queimadas
formidáveis que tudo consumiam. Jamais o mundo vira um desperdício tão completo
de uma flora tão valiosa devorada em turbilhões de fumo e chamas (Lamego, 1963,
p. 92).

Com a expansão dos cafezais, os povos originários que ainda resistiam na região pereceram tanto pelo combate, como pelas moléstias trazidas pelos fluminenses (Vieira, 2000; 
Oliveira, 2012). É durante o século XIX que o Rio de Janeiro vai se consolidar como a província mais rica do império, já inaugurado a partir de 1822 com a independência política do Brasil. Ainda assim, foi no Vale do Paraíba fluminense que todo processo de consolidação do Império, bem como seu enriquecimento se sucedeu.

E é nesse contexto, em que a riqueza arregimentada pelas aristocracias cafeicultoras fez surgir diversas sedes de fazendas, como é o caso da Fazenda Santo Antônio do Paiol. No próximo capítulo, elementos ligados ao processo de construção e cotidiano da mesma são explorados com o intuito de compreender a transição desta unidade produtiva que até então se dedicara sobretudo à agricultura, passando também a produzir serviços de hospitalidade comercial.

\section{A FAZENDA SANTO ANTÔNIO DO PAIOL: DA CAFEICULTURA HEGEMÔNICA AO PIONEIRISMO NA HOSPITALIDADE}

O Rio de Janeiro, a partir do século XIX, passa a suceder Pernambuco (com o Ciclo da Cana de Açúcar) e Minas Gerais (Ciclo do Ouro e Pedras Preciosas) como a região mais rica do Brasil. Isso, por si só, vai explicar em partes a sedimentação do poder econômico e político da região Sudeste até o século XX. A cafeicultura nos moldes de plantation fez com que unidades produtivas inúmeras surgissem por todo o Vale do Paraíba Fluminense. A riqueza advinda dos cafezais engendrou ainda mais a exploração da mão de obra escravizada, sendo sobretudo africanos e seus descendentes os responsáveis pela parte mais dolorosa do trabalho.

De acordo com Lamego (1963), o advento da expansão cafeeira, sobretudo na porção ocidental do Vale, também insere novos hábitos aos fluminenses. Afrancesaram-se os hábitos culturais, arquitetônicos e gastronômicos, enquanto se dava continuidade ao processo de entrechoque das culturas das três principais matrizes do povo fluminense, cuja força baseada no domínio do elemento europeu será indelével diante do processo de submissão imposto aos índios e africanos mesmo diante uma série de resistências.

A partir de 1819, novos elementos humanos passam a compor o mosaico étnico fluminense: chegam os imigrantes suíços, alemães, italianos, espanhóis, portugueses, finlandeses, japoneses, libaneses e sírios. Todos esses povos vêm a somar para o processo de formação das culturas da Serra do Rio de Janeiro, as quais assimilaram o espírito da identidade cultural brasileira (brasilidade) por intermédio de uma forte intervenção do então nascente Estado Nacional. 
A Fazenda Santo Antônio do Paiol é uma das poucas unidades estudadas nos municípios de Barra do Piraí e Valença que não se encontra agrupada no Tour da Experiência ${ }^{4}$ (D’Onofre, 2017). Fica localizada às margens da RJ 145, nas cercanias do bairro valenciano de Esteves. A família que liderou sua construção foi a de Francisco Martins Pimentel, o qual adquiriu as terras em 1821. De acordo com Novaes e Pozzobon (2008, p. 174),

\begin{abstract}
Exatamente na metade do século XIX, a fazenda serviu de dote a Manoel Antônio Esteves, que a recebeu como recompensa pelo seu casamento com a filha de Pimentel, Maria Francisca. O novo proprietário construiu rapidamente a nova sede, que foi feita com todos os requisitos exigidos de uma fazenda de café do período. É peculiar o local da implantação, no alto de uma colina, cercada de palmeiras imperiais. A construção da casa foi acompanhada pela prosperidade do cafezal, que atingiu sua melhor fase neste período.
\end{abstract}

Assim como as demais fazendas históricas, Santo Antônio do Paiol também surgiu por conta da lavoura de café, tendo Esteves papel central na expansão dos cafezais na região. Vindo de Portugal, Manoel Antônio Esteves nasceu em 1813, na região do Rio Minho e estabeleceu-se na região de Vassouras por volta dos anos 1840 (Mattos, 2019). Ao imigrar para ali, iniciou o processo de consolidação de uma casa de comércio, justamente para atender a demanda por bens de inúmeras ordens que vinham das elites de Vassouras. O sucesso de seus negócios o levou a consolidar casamento com a família de Francisco Martins Pimentel, próspero proprietário de terras na região de Valença.

Já em Valença, ao final do ano de 1850, Esteves casa-se com Maria Francisca das Dores Pimentel. Sua esposa era filha de Pimentel, também lusitano dos Açores, com Clara Maria Dutra, sendo ambos donos de vastas terras em Valença. Ao se casar com Esteves, Maria Francisca une seu patrimônio herdado ao ramo do comércio já desenvolvido por seu marido. Em pouco tempo, o casal começa a ganhar renome em Valença, a ponto de em 1853 conseguirem através da rotina de exploração já arraigada pela elite cafeeira, inaugurar a Fazenda Santo Antônio do Paiol, local de sua residência fixa. A Figura 1 mostra atualmente como está disposto o casarão que também é a sede da fazenda.

\footnotetext{
${ }^{4}$ Recuperado em 20, julho, 2017, de http://www.tourdaexperiencia.com.br/institucional.
} 


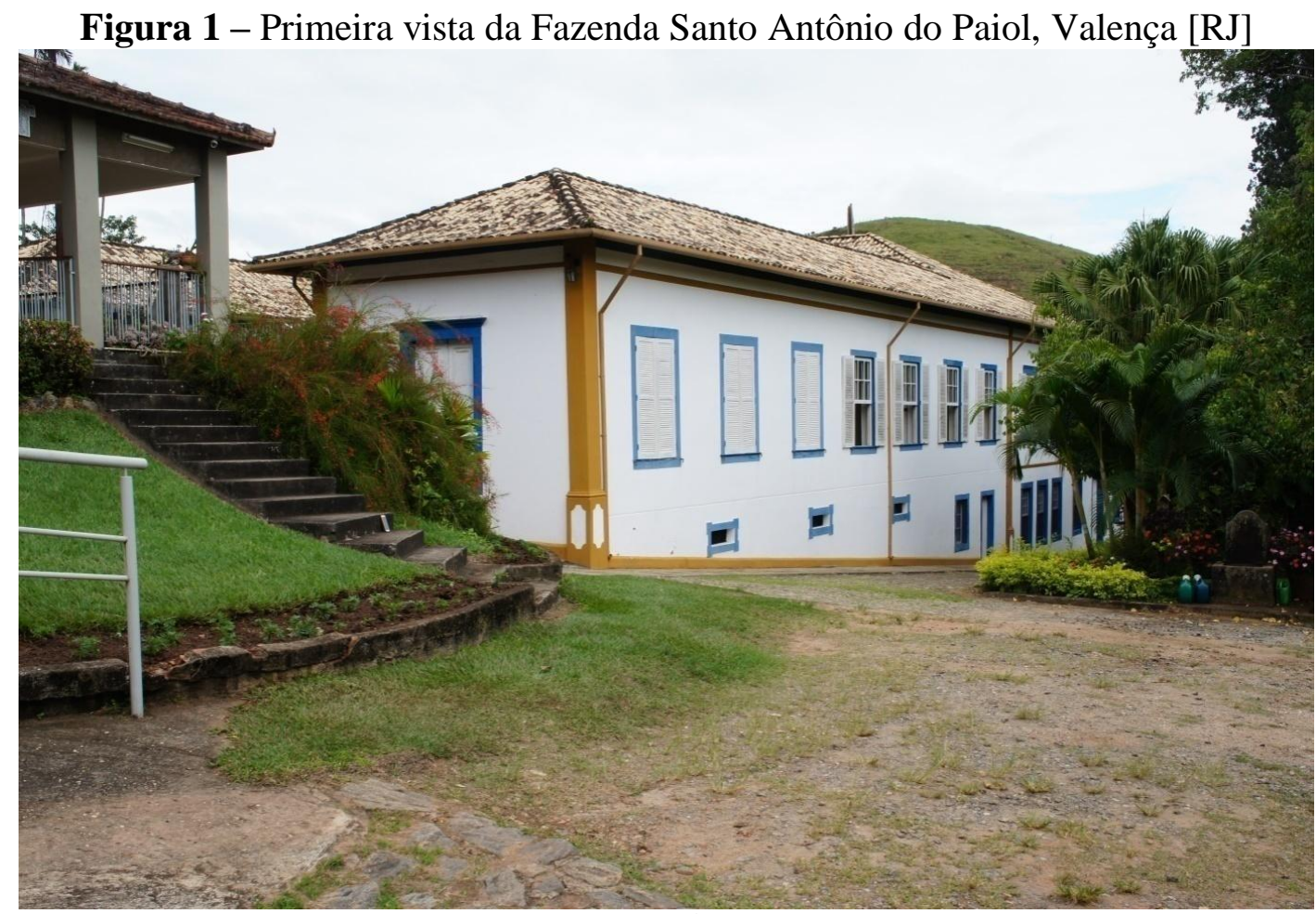

Fonte: Dan Gabriel D’Onofre ${ }^{5}$, [fotografia digital] 2017.

Com a nova sede inaugurada, Mattos (2019) revela que o estabelecimento de Esteves permitiu não só que o mesmo lograsse sucesso nos negócios comerciais em Valença, como passasse a manter boas relações com as demais figuras da elite cafeeira local. Ao aproximarse de Ilíada Mafalda de Souza Queiros, a Marquesa de Valença, Esteves pode atuar como seu procurador e responsável por propriedades diversas. Do mesmo modo, Mattos (2019) assinala que o maior feito de Esteves ainda em Valença se consolidou na construção da linha de ferro União Valenciana, a qual foi aberta em 1871 e conectava as cercanias aos demais ramais ferroviários do Rio de Janeiro e Minas Gerais. A partir desta ferrovia, não apenas sacas de café, mas pessoas e demais bens passavam a se deslocar pelos vagões que subiam e desciam as serras de Valença.

O desenvolvimento dos negócios de Esteves foi tamanho que, em tempo curto, possibilitou a ampliação dos cafezais através da exploração da mão de obra escravizada local. Com cerca de 600 trabalhadores escravizados, Esteves passou também a comprar não só mais fazendas, como também criou a firma exportadora "Esteves \& Filhos". A empresa tinha como finalidade, de acordo com Novaes e Pozzobon (2008), retirar intermediários da comercialização do café com transportadoras, pois podiam operar na negociação tanto no Rio

\footnotetext{
${ }^{5}$ As regras estabelecidas para catalogação das figuras usadas nessa pesquisa são baseadas na segunda edição do Código de Catalogação Anglo-americano (CCAA-2), na publicação "Graphic materials: rules for describing originals itens and historical collections", editada em 1982 pela Library of Congress, (a partir do CCAA-2), bem como no "Manual para catalogação de documentos fotográficos" da FUNARTE.
} 
de Janeiro, como em Santos. Em 1879, Francisco Martins Esteves faleceu no Rio de Janeiro, deixando sua herança ao seu filho mais velho, o qual não manifestava interesse em tocar os negócios da família (ibdem).

Entre adesões e vendas, as terras dos Esteves acabaram sendo administradas por Marcos Zacarias Manoel Esteves, neto do pioneiro. Enquanto o pesquisador conviveu na Santo Antônio do Paiol, o anfitrião atual destacava a história de Marcos e Francisca Olympia Alves de Queiroz Esteves (ver Figura 2) como um dos marcos da perspectiva de abertura da fazenda ao turismo.

Figura 2 - Apresentação da história de Marcos e Francisca, Fazenda Santo Antônio do Paiol,

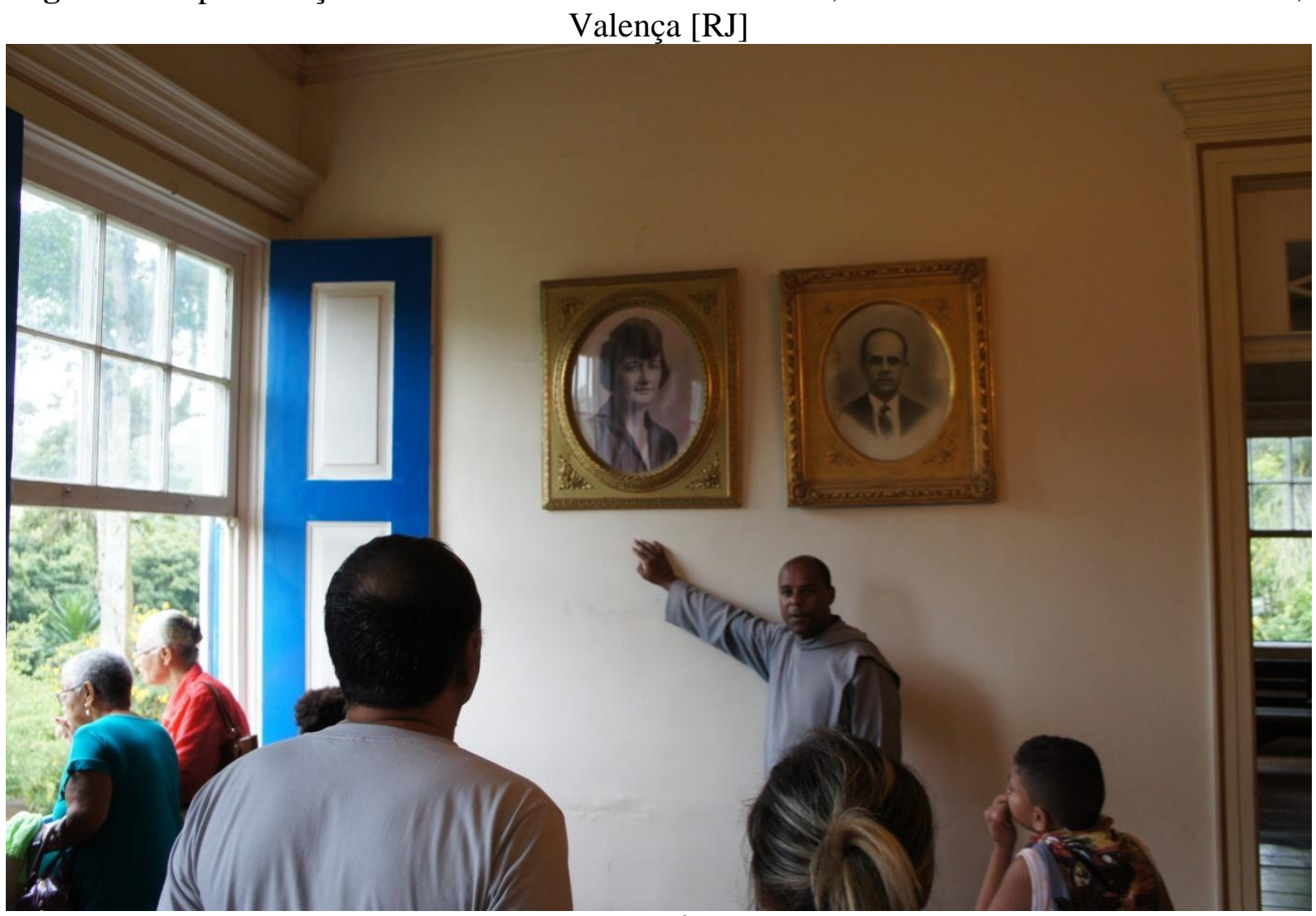

Fonte: Dan Gabriel D’Onofre ${ }^{6}$, [fotografia digital] 2017.

A visitação comercial efetuada nos dias de hoje não começa desse ponto, mas vale chamar atenção para a centralidade da figura de Dona Francisca. Segundo o anfitrião, Marcos a conheceu enquanto morou no Rio de Janeiro, sendo ela uma atendente de um restaurante vinda do Maranhão. A contragosto da família Esteves, ambos se casaram e, a partir desse momento, rejeitados do convívio com a rede de amigos e de negociantes. Como Marcos veio a falecer antes, Francisca se viu em meio à falência da atividade cafeeira, bem como com um

\footnotetext{
${ }^{6}$ As pessoas que estão nas imagens, além de cientes sobre a pesquisa, concordaram por meio de Termo de
} Consentimento a veiculação destas imagens (D’Onofre, 2017). 
farto legado material da família Esteves. Assim, segundo o anfitrião, houve por parte dela a iniciativa de inventariar e manter tudo que fosse ligado à memória da cafeicultura e da história da família.

Dona Francisca teve como conjuntura o que Vieira (2000, pp. 68-74) chama de "lenta agonia da cafeicultura fluminense”. Já nos fim dos anos 1870, a região do Vale do Paraíba passa a enfrentar problemas relacionados às opções agronômicas de cultivo do café. As escolhas pelo cultivo sem respeitar as curvas de nível, bem como a permanência do braço escravizado na condução dos processos de produção do café foram decisivos para que, aos poucos, o Rio de Janeiro passasse a não mais abarcar o que havia de pioneiro na cafeicultura. Ainda que entre 1891 a 1930 tivesse havido aumento na produção de café no Rio de Janeiro, isso se deveu tanto à demanda já consolidada pela $1^{\text {a }}$ Guerra Mundial e o período que antecedia a $2^{\mathrm{a}}$ Guerra Mundial, como também ao aumento das áreas de cultivo que se expandiram ao Noroeste Fluminense e até mesmo a algumas áreas de planície que até então não se dedicavam à cafeicultura (idem).

Vieira revela que, da mesma maneira que se constatava o fracasso da cafeicultura fluminense nas áreas pioneiras, o governo fluminense lançara mão de estratégias de substituir a mão de obra escravizada pela de imigrantes europeus, não tendo sucesso e abandonando-as em 1898. Na segunda metade do século XX, o governo fluminense não conseguiu empreender uma ação enérgica de núcleos de imigração no ocidente do Vale, pois, com pés de café velhos e terra exaurida era quase impossível manter imigrantes europeus nessa empreitada (Vieira, 2000). Dessa forma, Vieira aponta que a alternativa do governo foi incentivar a diversificação da produção agrícola, bem como inserir a produção pecuária na região.

Por não terem tido filhos, a herança de Dona Francisca foi legada pela Congregação da Pequena Obra da Divina Providência São Luis Orione em 1969. A instituição religiosa de origem italiana foi a alternativa encontrada por Francisca para a salvaguarda da memória que ela se lançou em preservar. Nesse sentido, a doação foi condicionada ao fato de que a ordem jamais poderia vender qualquer peça que há dentro da fazenda, bem como a própria.

Mas antes de isso ocorrer, Dona Francisca já abria sua fazenda para visitação como forma de auferir receitas e lidar com a escassez de recursos financeiros, causada pelo insucesso da cafeicultura e da pecuária administrada por ela. Assim, a forma como ela utilizou a cultura material ainda nos anos 1960 permite afirmar que os visitantes que circulavam pela rede ferroviária da Estrada de Ferro União Valenciana frequentaram enquanto lazer o espaço para apreciar os elementos salvaguardados pela mesma. A informação dada pelos atuais anfitriões comerciais revela que havia um fluxo, sobretudo de fieis da fé católica para as 
visitas na fazenda. Nesse sentido, ainda que de forma discreta, a Fazenda Santo Antônio do Paiol dá mostras de que fora a pioneira na concessão de serviços de hospitalidade comercial no circuito das fazendas Vale do Paraíba.

Assim, o legado cultural da cafeicultura imperial já começava a ser apreciado enquanto lazer em pleno início da segunda metade do século XX. A doação da fazenda para a Congregação da Pequena Obra da Divina Providência São Luis Orione permitiu que se iniciasse também um processo de uso que destoa, naquele momento, de todos os usos que a tecnologia da pecuária permitia se manifestar no território. Ou seja, para além da pecuária, a fazenda passou também a hospedar outras figuras religiosas que vinham não só do Brasil, mas também da Europa, buscar formação religiosa e meditação. Portanto, Santo Antônio do Paiol pode ainda apresentar mais dados referentes ao comportamento humano em relação à hospitalidade, colocando-a no rol de marcos do turismo no Brasil.

A visão de Dona Francisca já dava mostras de que essa cultura material, legada do período da cafeicultura imperial, em algum momento teria uma serventia que se expandiria ao seu domínio próprio, cujas relações tecidas pelas visitações davam mostras do início do movimento tecnológico ligado à hospitalidade comercial. Na década de 1990, ainda no rescaldo do processo de aquisição de fazendas históricas enquanto um elemento de distinção social por parte da elite fluminense, a ordem arrendou a fazenda para um casal do Rio de Janeiro, Maria Alice e Rogério Vianna, que realizou uma obra considerável na sede (Novaes \& Pozzobon, 2008). Ainda de acordo com o inventário, a iniciativa desse casal possibilitou que alguns documentos fossem encontrados junto ao porão da sede, a auxiliar a construção dos serviços de hospitalidade comercial.

Apenas com a virada do século XX, é que a ordem católica que tem a posse da fazenda passa a adentrar com mais afinco o universo turístico local. Até então, a expertise ligada ao hábito de hospedar religiosos e romeiros, que vinha ao monastério, estava apenas restrita ao segmento ligado à fé. A própria natureza da ordem religiosa contém elementos ligados à hospitalidade. A inspiração para a criação dessa Divina Providência partira de Dom Orione, em outubro de 1898. No ano seguinte, na cidade de Stazzano, Piemonte, é fundada a ordem de natureza eremita. De acordo com as informações contidas na página eletrônica da fazenda, embora a ideia de eremitério permita-se conceber isolamento entre os pares, os quais se dedicam a solidão em locais ermos para realização de suas orações, a ordem criada por Dom Orione se distingue pelos 
Eremitas da Divina Providência [...], sempre viveram e vivem em pequenas comunidades ou cenóbios, ao lado de antigos santuários, mosteiros ou lugares isolados, num estilo de vida simples e familiar, fraternalmente abertos ao acolhimento e à atenção aos fiéis, dedicando a sua jornada aos humildes serviços da casa e ao trabalho do campo (Fazenda Santo Antonio do Paiol, 2017).

Nesse sentido, embora seja uma oferta comercial, os serviços de hospedagem ${ }^{7}$ criados a partir de 2003 pela ordem se caracterizam como

O eremitério acolhe em sua hospedaria pessoas desejosas [sic] de aprofundar a própria fé, no silêncio, no recolhimento, reflexão e oração. Os eremitas exercem um apostolado no interno do eremitério, ajudando pessoas que necessitam de um conselho ou de ajuda espiritual (idem).

Antes mesmo de elaborarem o processo de oferta de serviços comerciais de hospedagem com cunho espiritual, a ordem eremita já realizava a oferta de visitações com vistas a angariar receitas com este serviço. Logo, a conservação da memória da cultura material já elaborada por Dona Francisca, assim como a reforma realizada pelo casal Vianna na década de 1990 são bases para que as técnicas se desenvolvam. Há de se dizer que, mesmo por ser uma ordem religiosa e estar isenta de arcar com as taxas de coligação ao Preservale ${ }^{8}$, a Fazenda Santo Antônio do Paiol deixou de participar do instituto em 2011. As alegações se devem ao excesso de reuniões sem resultados. Logo, pode-se inferir que as dinâmicas da instituição que congrega esforços para a preservação e turistificação das fazendas estivessem em conflito com a rotina do mosteiro.

A visitação começa pelo porão do casarão, onde os hóspedes geralmente costumam questionar se era a senzala da fazenda. Como as demais fazendas, Santo Antônio do Paiol não possui sua senzala erigida e aberta ao público. Dessa maneira, o anfitrião comercial na figura do frei Jerônimo explica que o porão além de não ser senzala, era uma das áreas funcionais do casarão. Na atualidade, uma série de coisas que remetem a vida do período da cafeicultura imperial A Figura 3 permite que se constate o legado conservado por Dona Francisca ainda na década de 1960.

\footnotetext{
${ }^{7}$ A fazenda presta o serviço espiritual, acolhendo grupos desejos em transcorrer dias de retiros espirituais, disponibilizamos 24 quartos todos eles com banheiros próprios e 2 camas de solteiro. Para tal serviço pede-se também adiantamento de 50\% e o valor pode ser depositado na mesma conta bancária citada acima (Fazenda Santo Antônio do Paiol, 2017).

${ }^{8}$ De acordo com Preservale (2011), suas iniciativas estão sempre "focalizando a revitalização de patrimônios históricos, culturais e ambientais que são a marca exclusiva dessa região, [a somar] esforços e parcerias e compartilhando o crescimento do turismo das economias locais, bem como o aumento do interesse acadêmico, cultural, histórico e ecológico sobre o Vale do Paraíba, o Ciclo do Café e a Mata Atlântica. A proposta do Preservale representa alternativa do desenvolvimento econômico sustentável que demandam hoje por uma estratégia de intervenção de múltiplas interfaces".
} 
Figura 3 - Coisas do cotidiano do século XIX e início do XX, Fazenda Santo Antônio do Paiol, Valença $[\mathrm{RJ}]$

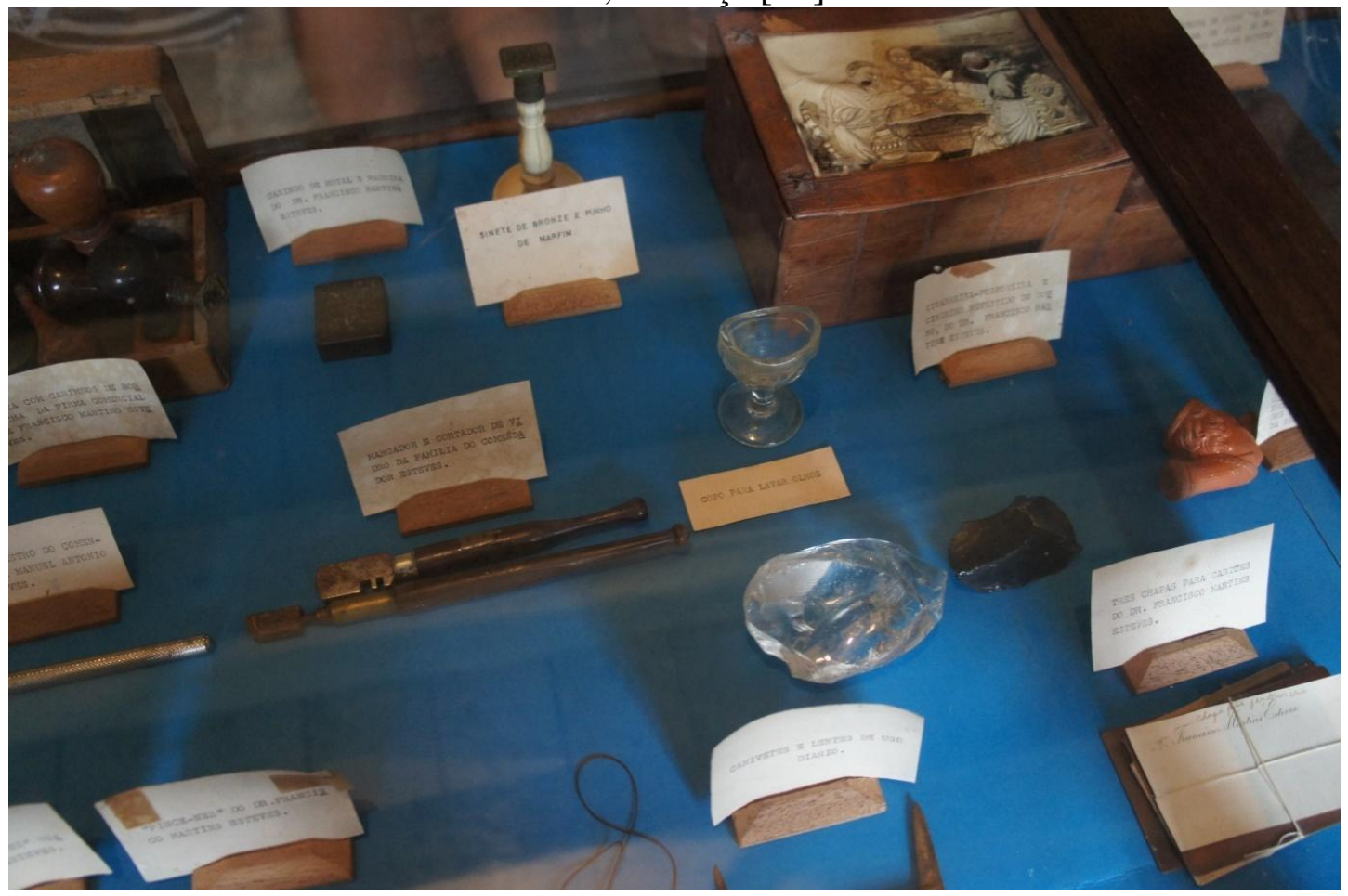

Fonte: Dan Gabriel D’Onofre, [fotografia digital] 2017.

Faltam indícios sobre os fatores motivacionais, bem como o desenvolvimento das técnicas de exposição que a mesma utilizara para expor o legado da família Esteves. Em pequenos pedaços de papel, escritos em máquinas de escrever, é possível constatar o trabalho que Dona Francisca iniciara ainda em pleno período em que a pecuária era hegemônica na região (1900-1980). De copo para lavar olhos, marcador e cortador de vidro, conjunto de cigarreira, fosforeira e cinzeiro de couro, dentre outras miudezas que faziam parte do cotidiano da família de seu esposo, Dona Francisca fora a pioneira na salvaguarda das coisas que foram parte de um mundo que hoje só existe por conta das histórias contadas por essas coisas.

O universo se descortina aos olhos de hóspedes que prestam atenção e manifestam as mais variadas dúvidas sobre as coisas que são acionadas durante a visitação. Sob uma série de vigas de madeiras encaixadas, as quais sustentam a estrutura do edifício, um armário de madeira maciça, com portas translúcidas por conta dos vidros, é possível ver como eram as farmácias que as fazendas possuíam no período da cafeicultura imperial (ver Figura 4). 
Figura 4 - A farmácia do período da cafeicultura imperial, Fazenda Santo Antônio do Paiol, Valença [RJ]

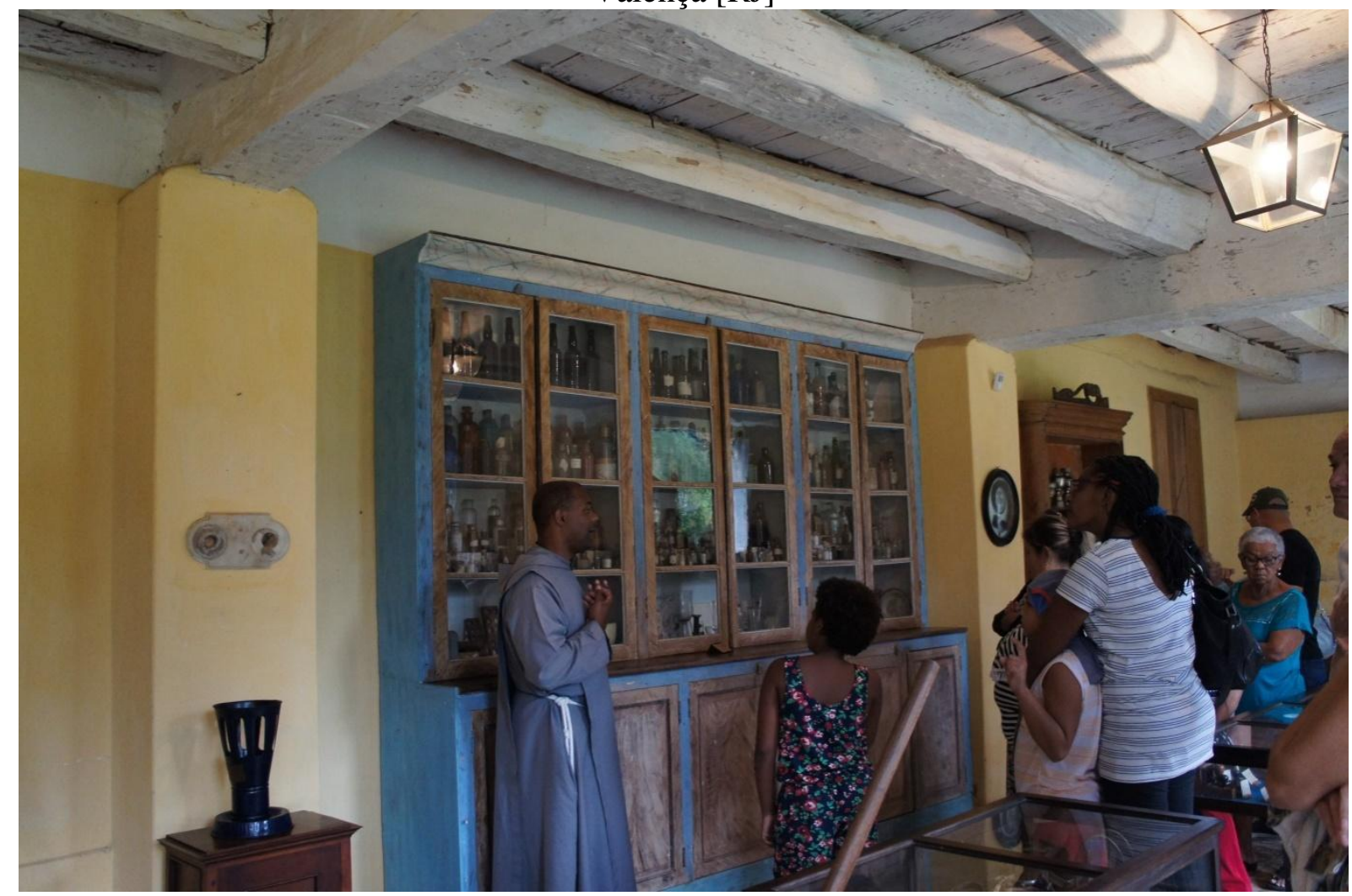

Fonte: Dan Gabriel D’Onofre, [fotografia digital] 2017.

Através da explicação, o anfitrião aciona a cultura material exposta nas prateleiras para dizer que devido ao preço que se empenhava na compra de um trabalhador escravizado, as fazendas costumavam a possuir farmácias para prestar socorros aos cativos. Ali, avisava-se que as moléstias poderiam ser causadas por iniciativas de castigos, da lida nos trabalhos junto aos cafezais, bem como a propensão aos acasos advindos por doenças inúmeras. A vida de um trabalhador escravizado durava em média algo em torno a 35 anos, sendo comum que muitos viessem a falecer ainda mais cedo se não houvesse essas farmácias, como a retratada na Figura 5.

A Fazenda Santo Antônio do Paiol ainda que não possua sua senzala em boas condições, restando-lhe apenas reminiscências (Novaes \& Pozzobon, 2008), guardou parte de seus instrumentos usados na tortura de trabalhadores escravizados. Um dos instrumentos que retratam a forma como se lidava com a força de trabalho no período da cafeicultura imperial, é o pelourinho (ver a Figura 5). 


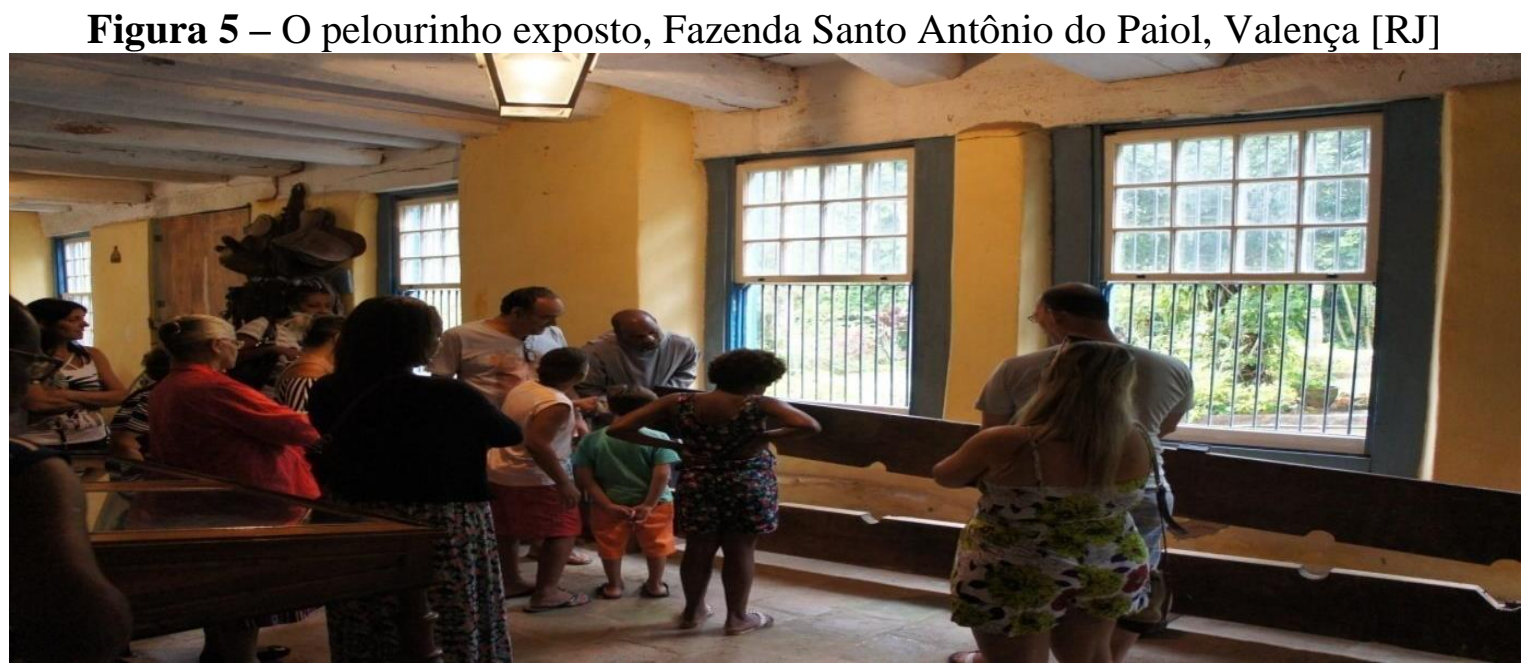

Fonte: Dan Gabriel D’Onofre, [fotografia digital] 2017.

Esse grupo de hóspedes vindos de Nova Iguaçu possuía como característica para além do fato de ser um daqueles perfis ligados às excursões organizadas por igrejas, mas também pela presença de um contingente expressivo de negros. As memórias do cárcere e do cativeiro acionavam uma espécie de remorso quando o anfitrião, também negro, prestava o serviço de exposição dos instrumentos de tortura. Ainda assim, havia uma série de iniciativas de fotografar esses instrumentos, embora o discurso por detrás desse serviço não apresentasse qualquer elemento sobre a questão da reparação à população negra.

O passeio pela casa permite que as dinâmicas da vida da família Esteves sejam recontadas através das louças, das mesas, quadros, peças de artes. $\mathrm{O}$ acervo mantido por Dona Francisca hoje é base para a permanência da organização de serviços de visitação. O fim da visitação se dá com a ida à loja mantida pela ordem. Elementos produzidos ali e vindos de outras localidades da região compõem a oferta de mercadorias por destinação.

Figura 6 - Lojinha da Fazenda Santo Antônio do Paiol, Valença [RJ]

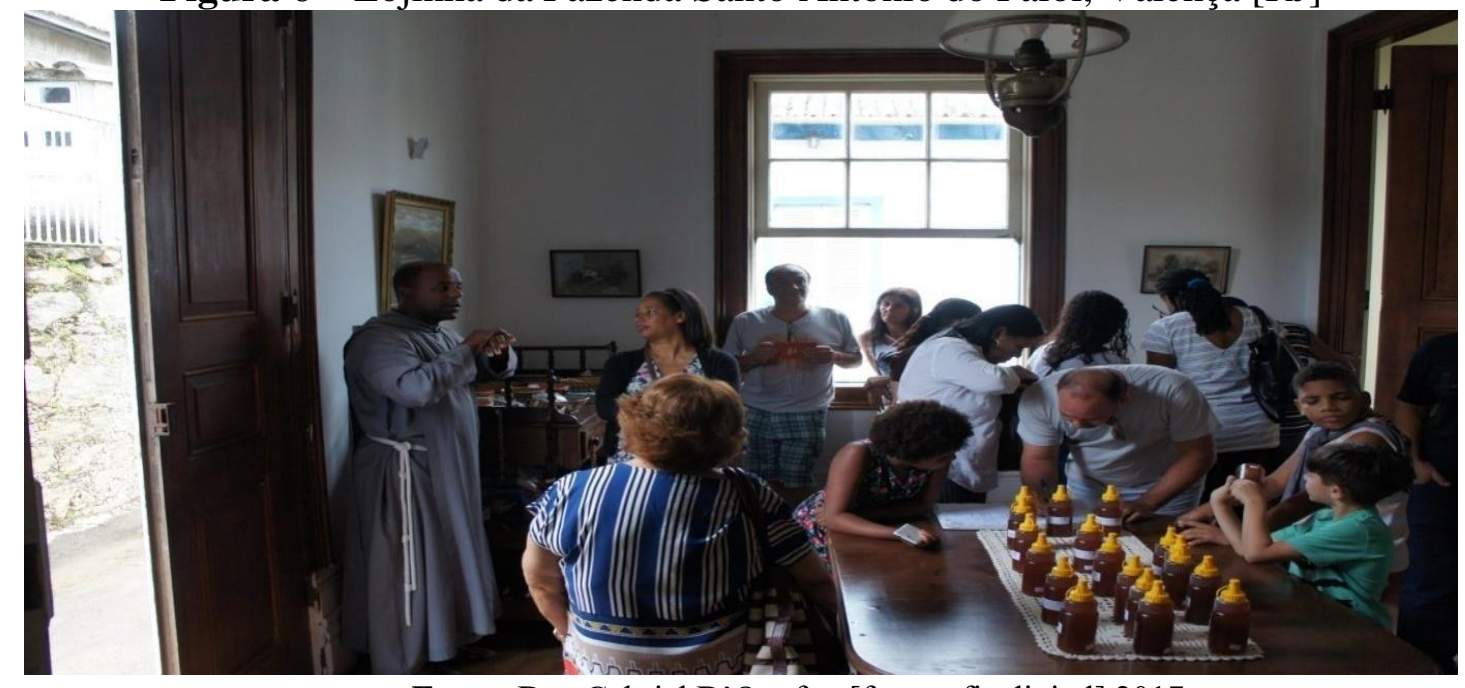

Fonte: Dan Gabriel D’Onofre, [fotografia digital] 2017. 
Ao andar pelos campos, a "peregrinação" pode ser levada através de produtos que remetam o processo de construção da identidade da fazenda. O grupo que esteve sendo acompanhado no dia da visita não era católico, a refletir na não aquisição de mercadorias destinadas à identidade e prática dessa religião. Ainda assim, o plantel de coisas como mel, pomadas naturais e alguns livros permitiam que os hóspedes que não professavam a fé católica pudessem adquirir a cultura material pensada a eles. Ainda assim, a maior parte das mercadorias por destinação se manifestava em escapulários, discos compactos de músicas religiosas (CD), velas, medalhinhas, bem como outros itens que compõem o rito católico apostólico romano.

O fim da visitação também é o momento em que os hóspedes efetuam a segunda parcela do pagamento. A fazenda funciona com as reservas mediante ao depósito de cinquenta por cento do valor dos serviços. Isso não impede que pessoas que estão a passar pela região e entrem na fazenda possa realizar o passeio, embora a consecução da atividade planejada com o anúncio antecedente permite uma melhor condução por parte dos anfitriões. No dia em que o pesquisador esteve presente, além da visitação, os hóspedes adquiriram o pacote com almoço incluído. No salão do almoço, a simplicidade é algo marcante na forma como se prepara a recepção para alimentar comercialmente comensais. Ainda que algumas regras fossem explícitas (ver Figura 7).

Figura 7 - Regras não obrigatórias do salão do restaurante da Fazenda Santo Antônio do Paiol, Valença [RJ]

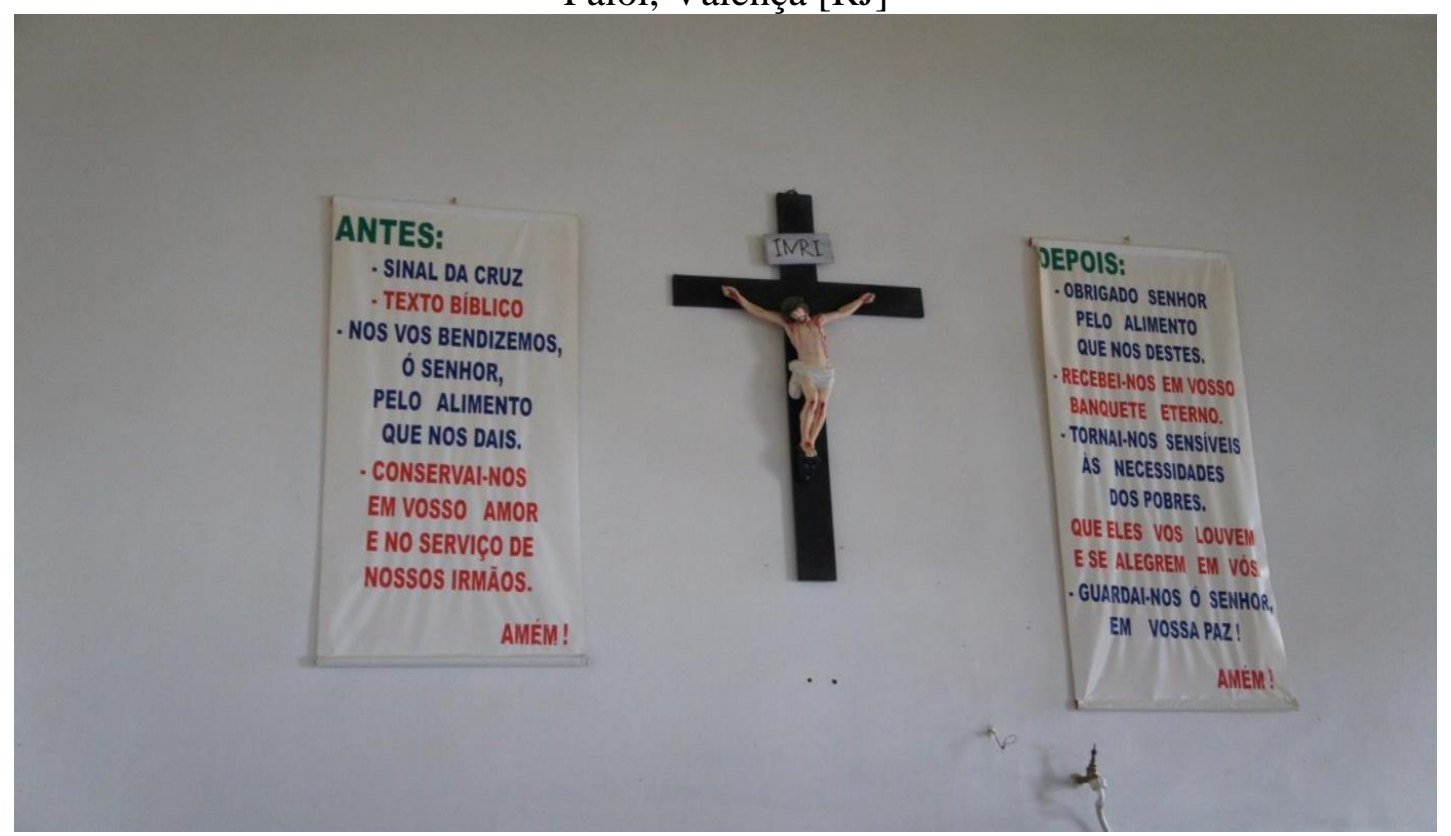

Fonte: Dan Gabriel D’Onofre, [fotografia digital] 2017. 
O estabelecimento dessas regras não é obrigatório, embora constem na paisagem com os banners fixados entre uma réplica de Cristo crucificado. Ou seja, a representação máxima da fé católica é ladeada por regras que podem não ser cumpridas por parte dos comensais. Ainda assim, a cozinha é comandada por 2 funcionárias, as quais também são responsáveis pela limpeza e higienização do recinto. O cardápio conta com a releitura de pratos elaborados nas cozinhas interioranas do Rio de Janeiro. A Figura 8 mostra como são as técnicas de serviço empreendidas para agradar aos comensais, assim como os pratos elaborados.

Figura 8 - Alimentos servidos no almoço da Fazenda Santo Antônio do Paiol, Valença [RJ]

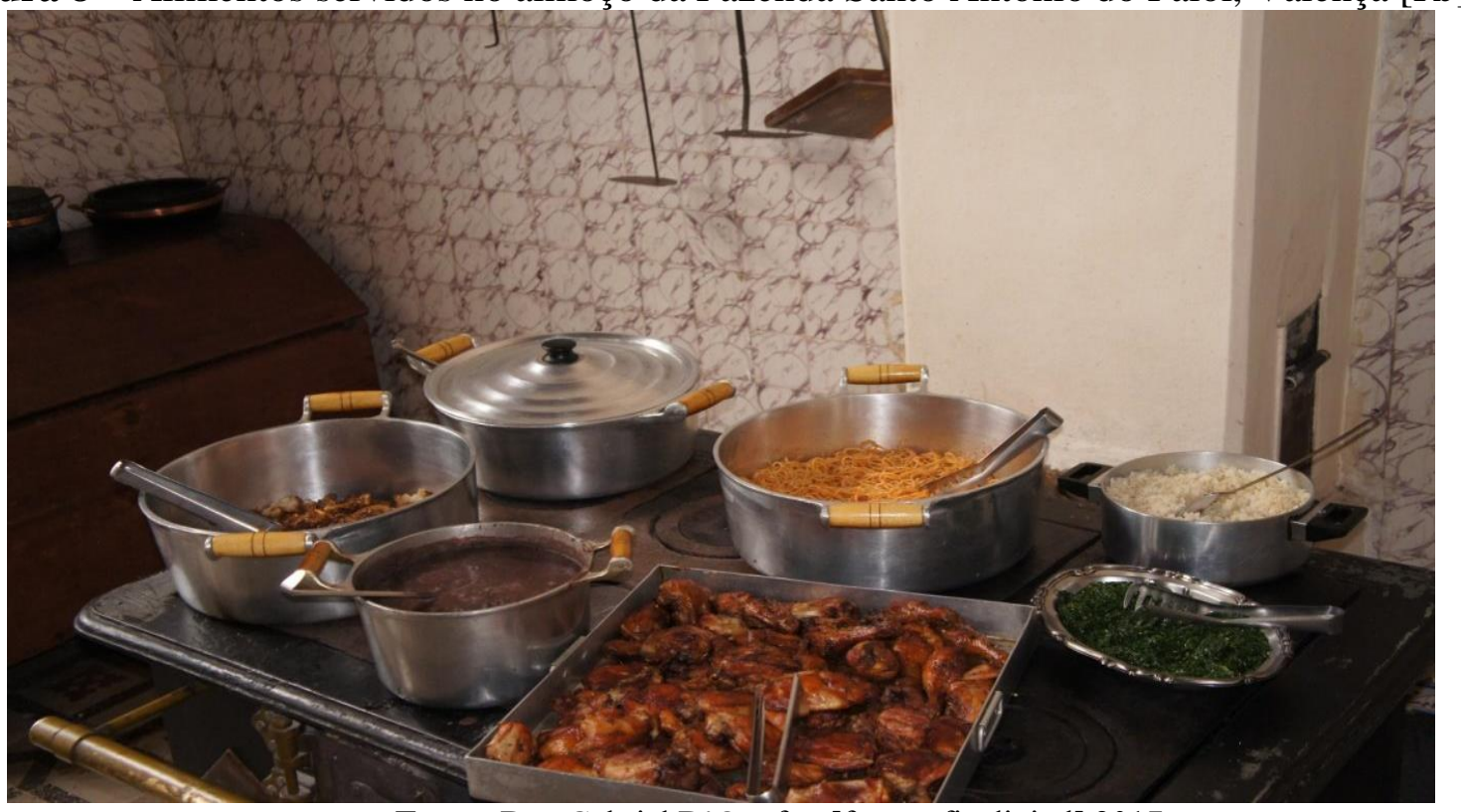

Fonte: Dan Gabriel D’Onofre, [fotografia digital] 2017.

O cardápio oferecido condiz com o que é geralmente servido nas demais fazendas do Vale. A típica combinação de feijão preto com arroz se junta à carne suína assada, coxas e sobrecoxas de galinha assadas, couve manteiga refogada com alho. Há também a oferta de macarrão ao molho de tomate, bem como, numa outra bancada, a oferta de angu (em ponto de polenta) com cobertura de carne bovina moída e cozida em molho de tomate (algo bem próximo ao ragu), além de salada (alface, tomate e cebola) e queijo parmesão (ver Figura 9). 
Figura 9 - Outros alimentos servidos no almoço da Fazenda Santo Antônio do Paiol, Valença $[\mathrm{RJ}]$

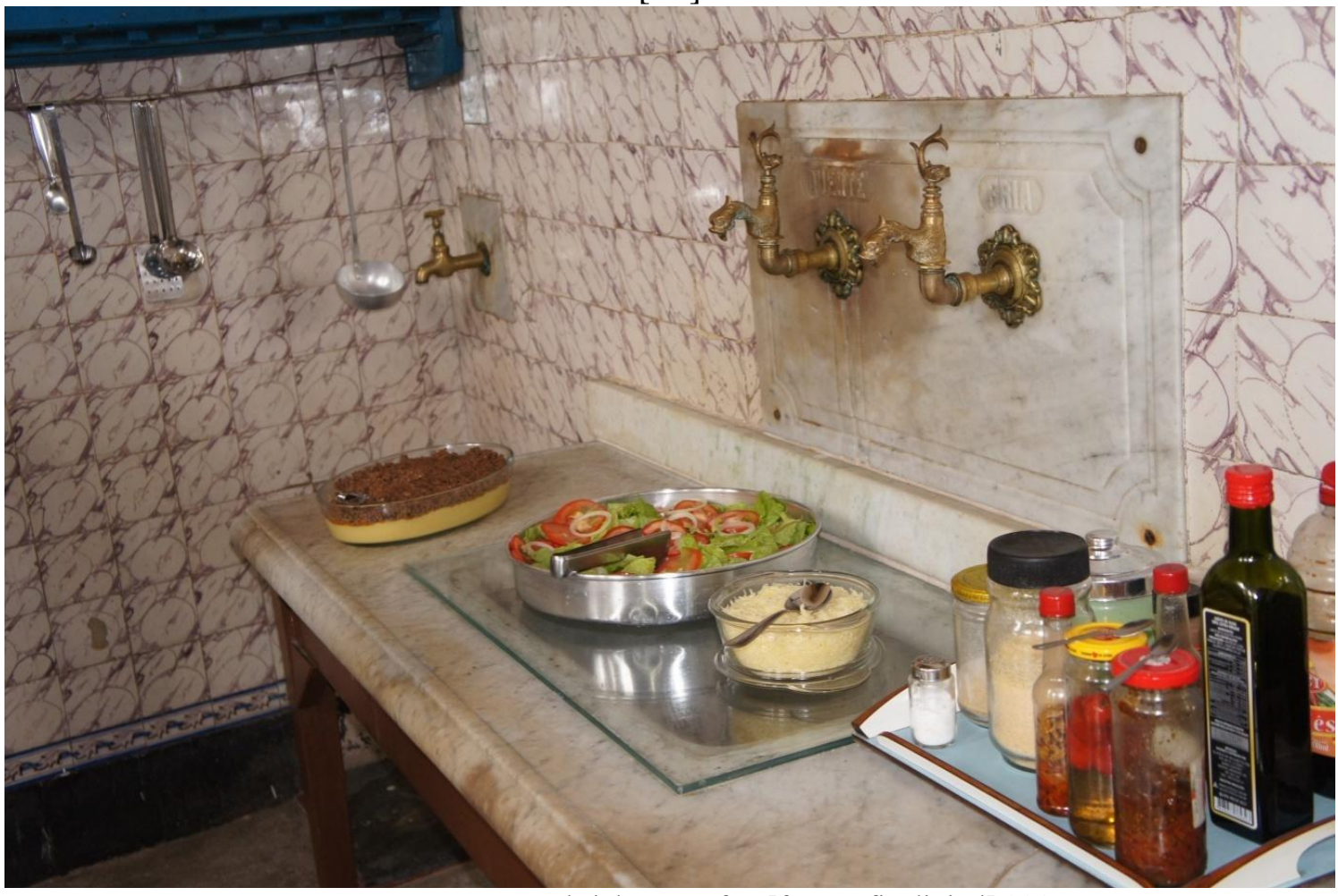

Fonte: Dan Gabriel D’Onofre, [fotografia digital] 2017.

A Figura 9 prova a marca que a imigração italiana deixou na região. Após a Abolição, houve um fluxo de imigrantes italianos para a região de Valença ${ }^{9}$, sendo um elemento de mudanças na gastronomia do município, sobretudo com a difusão das massas à base de trigo. Ainda segundo os anfitriões, boa parte desses imigrantes italianos não se adaptou a Valença, tendo migrado para outras regiões do estado do Rio de Janeiro, bem como a Minas Gerais. Esta figura ainda permite ver a oferta de condimentos e acompanhamentos como pimentas em conserva, molhos de pimenta, molho inglês, vinagre de vinho tinto, sal e farinha de mandioca.

A própria variedade das culturas que veio contribuir ao processo de formação da região está presente na forma como os anfitriões pensam a oferta gastronômica. Está incluso no preço acertado a oferta de bebidas (refrigerantes da Coca Cola, bem como suco de laranjas e água), além de sobremesas à base de doces de compota feitos com frutas da fazenda. Segundo os anfitriões, antigamente se serviam doces como pudins e pavês, mas os hóspedes na qualidade de comensais alertavam que seria interessante ter os "doces de fazenda", ou seja, as compotas com frutas cultivadas na região, servidas com queijo branco e café.

\footnotetext{
${ }^{9}$ De acordo com a Secretaria de Cultura e Turismo de Valença, a presença dos italianos foi responsável pela dinamização da economia, bem como a industrialização ligada aos têxteis. Um dos distritos de Valença chama-se Pentagna, referência à imigração que houve na região, sendo o mais atrelado à dinâmica do município que possui diversos distritos com relações mais profundas aos limítrofes.
} 
O salão do restaurante (ver Figura 10) não conta com serviços de atendente, sendo os próprios comensais responsáveis pelo serviço de escolher seus alimentos e bebidas, bem como devolver copos, talheres e pratos à copa. Elementos da fé católica estão presentes em todos os espaços em que as refeições são feitas.

Figura 10 - Comensais no salão do restaurante da Fazenda Santo Antônio do Paiol, Valença

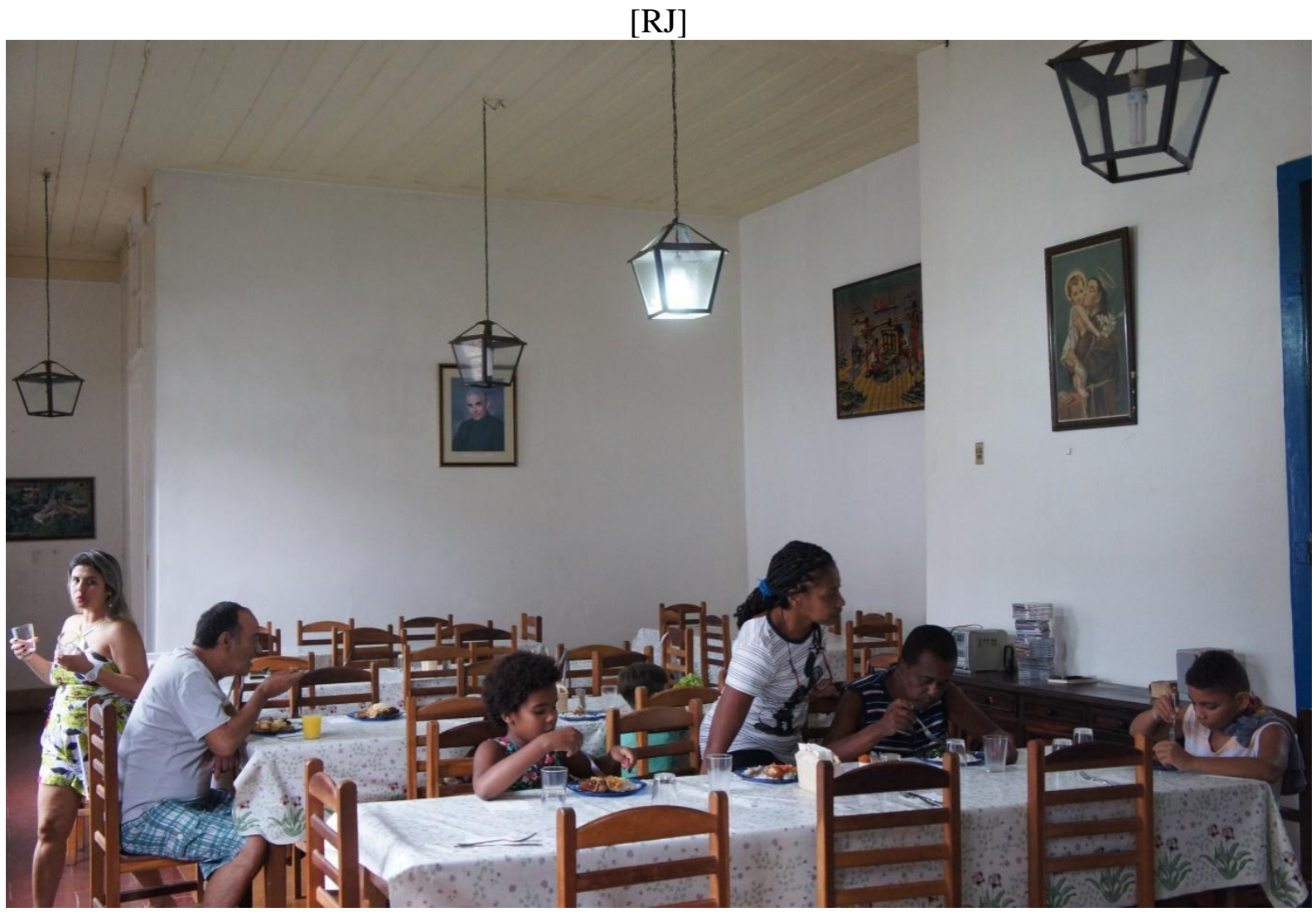

Fonte: Dan Gabriel D’Onofre, [fotografia digital] 2017.

A relação para com os hóspedes na qualidade de comensais sempre foi mediada pela questão religiosa, segundo os anfitriões. De acordo com eles mesmos, jamais tiveram problemas com seus hóspedes, sendo possível interpretar que a atmosfera de participação do processo de produção e consumo do serviço em meio ao ambiente religioso caracterizam a forma como as pessoas tendem a se portar. Assim, ainda que os comensais não pratiquem ou professem a fé católica, a ambiência de um monastério que se põe como principal diferencial da Fazenda Santo Antônio do Paiol dá a tônica de austeridade e pacifismo. Os projetos futuros giram em torno ao aprimoramento do que já é servido pela fazenda, a qual produz também plantas ornamentais, mel, além de ter terras arrendadas para criação de gado bovino. 


\section{REFLEXÕES FINAIS}

Ainda que seja inusitado rememorar, o passado econômico do estado do Rio de Janeiro deve aos Ciclos da Cana de Açúcar e do Café parte de sua memória e identidade. $\mathrm{Na}$ atualidade, a economia fluminense, mesmo que apresentando problemas estruturais e políticos, possui como primazia o setor de serviços como ponta de lança na geração de emprego e renda. Ainda assim, há uma certa predileção pelo escanteamento sobre os estudos ligados aos serviços, sobretudo no conjunto do interior do Rio de Janeiro e sua memória.

Em pleno município de Valença, ao sabor não apenas da maneira como a cafeicultura era conduzida pelas elites local, dentro delas, havia uma espécie de predileção pela manutenção do poder. Nesse sentido, a Fazenda Santo Antônio do Paiol, a qual é erigida por Manuel Antônio Esteves, simboliza um elemento de reflexão importante não apenas sobre os regimes tecnológicos (Trigueiro, 2009) que se sucederam ali, mas também sobre a finalidade deste espaço. A opção por uma pesquisa qualitativa, com instrumentais de aproximação de respondentes, bem como a possibilidade de retratar as realidades investigadas dão a tônica de que Santo Antônio do Paiol guarda em si muitos processos de inovação.

Se a cafeicultura permitiu que os Esteves pudessem comungar com a elite agrária valenciana, a ponto de expandir seus negócios para além da produção do café, mas a gestão de outras fazendas e firmas, o desinteresse em ter o patrimônio da família sob a posse de quem não era nem dono de comércio, nem ligada às famílias da aristocracia cafeeira, imputou que alternativas fossem pensadas. Ao passo que a cafeicultura fluminense passava pela "lenta agonia", abandonada à própria sorte, Dona Francisca Olympia Alves de Queiroz Esteves que era rejeitada pela família de seu esposo, Marcos Zacarias Manoel Esteves, passou a inventariar de modo espontâneo todo o legado material dos Esteves.

O que o casarão da Santo Antônio do Paiol possuía, passou a ser elementos de catalogação e exposição por Dona Francisca ainda na década de 1960. Ao relacionar a fazenda enquanto herança à Igreja Católica, houve uma espécie de parceria envolvendo fiéis que passavam a visitar Santo Antônio do Paiol com o intuito não apenas de conhecer o legado da cafeicultura imperial, como também contribuir financeiramente com os rendimentos de Dona Francisca. Assim, em pleno início da segunda metade do século XX, o município de Valença, no Sul Fluminense, pode abrigar uma iniciativa de comercialização da hospitalidade enquanto movimento de reprodução social de uma viúva.

Talvez, Dona Francisca, vinda do Maranhão, não soubesse que esse movimento ganharia fôlego a ponto de hoje ser a atividade turística a grande responsável pela 
revitalização de diversos casarões e sedes de fazendas históricas pelo Vale do Paraíba. Tais iniciativas dela consubstanciaram o que hoje tem sido desenvolvido pelos atuais anfitriões comerciais ligados à Igreja Católica. Por fim, reafirma-se que as bases para o desenvolvimento turístico do Vale do Café fluminense se fundamentam em histórias ainda desconhecidas, as quais a academia e sociedade precisam trazer à tona para credenciar o pioneirismo de quem de fato iniciou todo processo de promoção da cultura material da cafeicultura imperial fluminense.

\section{REFERÊNCIAS}

Camargo, L. O. L (2003). Os domínios da hospitalidade. In: Dencker, A. F. M., \& Bueno, M. S. (Org.). Hospitalidade: cenários e oportunidades. São Paulo: Pioneira Thomson Learning.

D’Onofre, D. G. (2017). Hospitalidade como tecnologia no Vale do Café fluminense do século XXI: produção e consumo. Tese de Doutorado em Ciências Sociais em Desenvolvimento, Agricultura e Sociedade, Instituto de Ciências Humanas e Sociais, Universidade Federal Rural do Rio de Janeiro, RJ, Brasil.

Lamego, A. R. (1963). O homem e a serra. Rio de Janeiro: Divisão Cultural.

Lashley, C. (2004). Para um entendimento teórico. In: Lashley, C., \& Morrison, A. Em busca da hospitalidade: perspectiva para um mundo globalizado. Barueri: Manole.

Mattos, R. C. O. (2019). Manuel Antônio e a União Valenciana - Comendador. In: Fazenda Santo Antônio Do Paiol. Valença/RJ.

Novaes, A., \& Pozzobon, F. (2008). Ficha técnica do inventário da Fazenda Santo Antônio do Paiol. In: Oliveira, T. N. K. (Coord.). Inventário das Fazendas do Vale do Paraíba Fluminense. Rio de Janeiro: INEPAC, ICCC, Instituto Light.

Oliveira, E. S. C. (2012). O Paradigma da Extinção: Desaparecimento dos Índios Puris em Campo Alegre no Sul do Vale do Paraíba. Anais do Encontro Regional de História da ANPUH-Rio, São Gonçalo, RJ, Brasil.

PRESERVALE. (2011). Conheça a Presevale. Rio de Janeiro. Recuperado em 14, julho, 2015, de http://www.preservale.com.br/conheca-a-preservale.

PRESERVALE. (2011). Roteiros do Vale do Café. Rio de Janeiro. Recuperado em 15, abril, 2017, de http://www.preservale.com.br/conheca-a-preservale/roteiros-turisticos.

Rio de Janeiro. (2014). Mapa do Estado do Rio de Janeiro - Regiões de Governo e Municípios - 2014. Rio de Janeiro: CEPERJ.

Trigueiro, M. G. S. (2009). Sociologia da tecnologia: bioprospecção e legitimação. São Paulo/SP: Centauro Editora.

Vieira, W. (2000). Apogeu e decadência da cafeicultura fluminense (1860 - 1930). Dissertação de Mestrado em História Econômica, Instituto de Economia, Universidade Estadual de Campinas, Campinas, SP, Brasil. 
CORDEIRO, D. G. D'O. A. S. (2020). Fazenda Santo Antônio do Paiol, Valença/RJ: pioneirismo em serviços de hospitalidade. Revista de Turismo Contemporâneo, 8(1), 17-40.

https://doi.org/10.21680/2357-8211.2020v8n1ID18530 